This article was downloaded by: [University of Sussex Library]

On: 18 January 2015, At: 18:46

Publisher: Routledge

Informa Ltd Registered in England and Wales Registered Number: 1072954

Registered office: Mortimer House, 37-41 Mortimer Street, London W1T

3J H, UK

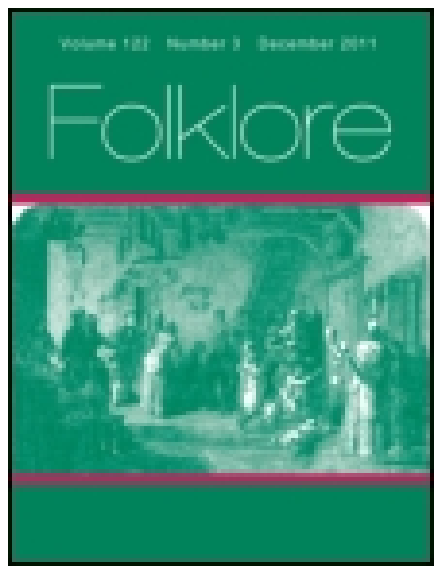

\title{
Folklore
}

Publication details, including instructions for authors and subscription information:

http:// www. tandfonline.com/loi/ rfol20

\section{Stray Notes on the Folk-Lore of Aberdeenshire and the North- East of Scotland}

David Rorie M.D.

Published online: 01 Feb 2012.

To cite this article: David Rorie M.D. (1914) Stray Notes on the Folk-Lore of Aberdeenshire and the North-East of Scotland, Folklore, 25:3, 342-363, DOI: 10.1080/ 0015587X. 1914.9718828

To link to this article: http:// dx. doi.org/ 10.1080/0015587X. 1914.9718828

\section{PLEASE SCROLL DOWN FOR ARTICLE}

Taylor \& Francis makes every effort to ensure the accuracy of all the information (the "Content") contained in the publications on our platform. However, Taylor \& Francis, our agents, and our licensors make no representations or warranties whatsoever as to the accuracy, completeness, or suitability for any purpose of the Content. Any opinions and views expressed in this publication are the opinions and views of the authors, and are not the views of or endorsed by Taylor \& Francis. The accuracy of the Content should not be relied upon and should be independently verified with primary sources of information. Taylor and Francis shall not be liable for any losses, actions, claims, proceedings, demands, costs, expenses, damages, and other liabilities whatsoever or howsoever caused arising directly or indirectly in connection with, in relation to or arising out of the use of the Content.

This article may be used for research, teaching, and private study purposes. Any substantial or systematic reproduction, redistribution, reselling, loan, sub-licensing, systematic supply, or distribution in any form to anyone is 
expressly forbidden. Terms $\&$ Conditions of access and use can be found at http://www.tandfonline.com/page/terms-and-conditions 


\title{
COLLECTANEA.
}

\author{
Stray Notes on the Folk-Lore of Aberdeenshike and the \\ NORTH-EAST OF SCOTLAND. \\ A Legend of Buried Treasure.
}

"IN one of the fields of the Kirktown bordering with Oldyleiper, at the base of a hillock, is a small loch or morass, where it is said a large copper vessel or kettle full of shining gold is hid, and that several attempts were made to find it out, but by some unforeseen event happening they always proved unsuccessful. The last person engaged in a search for this treasure, by perseverance and hard labour, had overcome almost every obstacle, and it was almost within his grasp, when he heard a voice shouting aloud, 'The kirk and manse are on fire.' The gold-seeker ran to the top of the hillock, in full view of the church and manse, but finding he had gone on an April errand returned with all haste to the 'pose,' when, behold, he could scarcely recognise the spot where he had spent so many hours of toil and labour. All was covered over again in its usual form, and seeing his hopes thus frustrated he abandoned the project; so here it may still be supposed to be guarded by some supernatural being who has the power to defeat every attempt made to remove its precious charge." (Dinnie, History of Birse.)

A similar story is told of the Corbie Pot, a deep pool in the Crynach burn, parish of Maryculter, Kincardineshire, and also of a pool in the Culter burn, parish of Peterculter, Aberdeenshire. ${ }^{1}$

'A similar Buried Treasure story comes from the Rose Hole, Beckhampsted Common, Hertfordshire, where an old man named Rose is said to have discovered that a chest of gold was buried. When the diggers found an iron chest, one of them exclaimed, "Dang it, Jack, here it is!" on which the 
Fun ack Fair.

"The ancient name of the f arish [Botriphine] was Fumack Kirk, so called from S. Fumack, the patron saint. A little below the Established manse is S. Fumac k's Well. An annual Fair is held in February, on a Green on the o sposite side of the Railway line from the Well. According to a " $L$ escription of the Parish," circa 1 726, the "wooden image is washed yearly, with much formality, by an old woman (quho keeps it) at his Fair on the third of May, in his own well there.' The Image, having been swept away by a flood of the Isla, was carried down o the mouth of the Deveron, where it was stranded, and afterward $\mathrm{s}$ burned, as a monument of superstition, in presence of the Par sh Minister. The old custom of a game at Football is still pract sed at Fumack Fair. Formerly the Gudewives, having 'brewed heir brewster,' used to shake their bags over the still for luck. "They believed that if the whisky did not operate so as to make the men fight at the Fair and "draw bluid," it would not be a gooc season following." (Gordon, Book of the Chronicles of Keith, p. 443.)

With the above ritual washing of an image, compare the following :-

"In a Niche in the north wall of the church [of Ruthven] is placed the Effigy of Thoma: Gordon of Daach, i.e. "Tam o' Riven," who fought the Mork of Grange. The effigy is cut in stone, and is known by the : lame of "Tam o' the stane." The Warrior is in full armour, wit । his sword by his side. The visor of the helmet is raised, sho wing the features, which are much obliterated by long exposur a to atmospheric influences. No inscription is now to be seer, but some of the older Inhabitants say that there was an Inscri tion on the Sword-belt round the body. The late Gordon of ' raig repaired The Tomb of Tam;and also an old woman white-washed the Figure annually." (Gordon, op. cit., p. 409.)

sides of the pit fell in, and they $h, d$ barely time to escape premature burial. When they returned next morning they could find no trace of the treasure. W. B. Gerish, IIth Series Notes and Queries, vol. i. p. 306.-EDitor. 


\section{Leechcraft and Witchcraft.}

The following account of "the Muckle Wheel Ban'," is taken down from the description of an old man, a native of the glen of Cushnie, West Aberdeenshire. The incident narrated actually occurred in the aforesaid glen some sixty years ago, and its truth can be vouched for.

An old farmer, having lost several of his calves through sickness, thought it advisable to mention the fact to Nannie, who had the reputation in the glen of being a "canny wifie," and with whom he happened to be on very good terms. He stated that another of his calves was ill, and Nannie said, "We'll pit it through the Muckle Wheel Ban', Sanners." (The "muckle wheel" was the driving wheel of the old-fashioned spinning-wheel which was driven by hand, by placing the hand on the top of the wheel, and giving it a strong, sharp, backward turn. It was connected by a band-" the muckle wheel ban'"-with the spindle, and was at least three times the circumference of the later type of wheel which was driven by a treadle. Only an expert could use it, from the fact that the right hand was constantly occupied with the driving of the wheel.) Having only one calf left the farmer was naturally very solicitous for its well-being, and said so to Nanny. The calf was accordingly brought into the house and the wheel set in motion. Having passed the calf through "the ban" Nanny gave it a sound smack on the back and said, "Ye'll live to be a gey ox yet and gang i' the ploo."

In further conversation with the farmer she remarked, "They're nae far awa that's interferin' wi' yer caur [calves], Sanners." "Nay, Nanny?" "Na, Sanners, they're nae that! They'll be comin' in sometimes to see ye, bit jist meal doon some breed in a sup milk, an' gae them that to drink. They'll nae be for takkin' ' $t$ at first, but press them to tak' it, an' try an' spull some o' the milk on them an' they'll tak' it quick eneuch efter that." The amount of pressure that had to be exercised, or the celerity with which the proffered refreshment was taken, was evidently the test of guilty or not guilty as regards meditated evil towards the person visited.

The same informant also recounted the following incident which happened in his own family. On one occasion his father 
had been at a meat market, and had returned home with a lusty porker of some six weeks' old in a poke (bag) slung over his shoulder. On entering his house he flung down the poke in a half-hearted way and said, "There'll be little thrift wi' that beast!" "Oh, fat wye that?" asked his wife. "Weel, I met Mary D. on the road." Some six months after this, on returning from his day's darg, he was made acquainted with the painful fact that his pig had choked. "I tellt ye Mary wad dee't" (do it) was his comment.

Following close on this catastrophe a crofter from the "back end" of the glen was one night wending his way home, "well primed," the priming, no doubt, being largely the illicit product of the glen. The night was dark and wild, and as the said Mary's Sheilin' was not far off the crofter's route, he thought it a suitable occasion for giving Mary "a line of his min" "regarding her cantrips and general behaviour. In due time he reached Mary's abode, and as no light was visible he had a difficulty in finding the door. He knocked without reply and knocked again. Then, finding the door "off the latch," he walked warily in. In the dim light of a dying peat fire he spied a female figure smoking a pipe by the fireside. Without turning her head to see who her visitor was she addressed him in the following words, "In the name o' God, fat brings ye here in sic a nicht, Jeems?" Jeems explained in strong and uncomplimentary language the reason of his visit, and having exhausted his store of expletives he drew himself up to his full height, and as a parting shot declared, "Ye chokit Willie Tamson's pig last week; but jist try yersel wi' me, ye bitch!" It is recorded that from this date, having cowed the witch, Jeems prospered in all his worldly affairs, while Mary held him in great respect to the end of her days. (From notes given me by Mr. J. R., Peterculter.)

The afore-mentioned Mary D. was looked on as a witch, and the usual tale of her turning herself at will into a hare was prevalent in the district.

In the parish of Strachan, Kincardineshire, within the last twenty years, a young servant girl declined to skin a hare which her mistress handed over to her. The girl's refusal was voiced thus : "Na, na, it micht be somebody's granny !" 
Fairies.

In the same glen of Cushnie one old man never passed the Fairy Hillock there without holding his cap on, as he always declared the proximity of the hillock made his hair stand on end.

\section{Communing with the Dead.}

At Coull an old couple lived on a croft-"a sma' croft wi' twa coos." They lived happily together. On the man's death his wife kept on the croft, but whenever she bought or sold anything she always went to the old man's grave and explained the whole matter to him. He had been a great user of snuff, and on these occasions she always deposited a little heap of snuff on the grave, so that he might regale himself with it till her next visit. (Told me by $\mathrm{H}$. R., aged 75, as having occurred in his youth.)

At Tarland, as a boy, the same narrator was badly scared while coming through the kirkyard at night by "something white" moving about below a flat gravestone supported on four short pillars. Investigation proved this to be a woman whose husband had been buried there some time previously. She had been a "bad 'umman," and her regret made her come there nightly to commune with the dead.

"An old story is still in remembrance about one of the tenants of the ale-house kept at the churchyard of Birse, Aberdeenshire. It is said that having had the misfortune to lose his wife, he, after having her decently buried in the churchyard behind his house, invited his neighbours who had attended on that melancholy occasion to partake of some refreshment before leaving. This they all agreed to, and after consuming a good dinner and several "cups of nappie ale" each, they naturally conjectured that a "jine" would not be out of the question, and as they were now in good spirits, and had been so handsomely treated, before parting they were willing to be their "pint a piece." But the landlord was a man of modesty and feeling, and would not consent to this proposal. However, the cash was collected and laid on the table, and of course he soon gave way to the majority, upon condition of having the liberty to enquire of his wife, and if she gave her consent he would make no objection. This they all agreed to, 
and away he went to the grave of his newly-buried wife, from which the question, "Will I sell them drink, Nanny?" found answer, "Hae they ony siller, John?" "Awat they hae plenty o' siller." "Weel, weel, gie ye them drink as lang's they hae siller, an' ye'll get plenty o' guid auld bottle't ale i' the amery ahint the hallin door." Some wag in the company had no doubt assisted the dead woman in answering this question." (Dinnie's Account of the Parish of Birse, Aberdeen, 1865.)

The wag may have assisted in the answer, but the fact remains that the man went out to commune with the dead, as in the Coull case.

\section{Funerals.}

Michie (Deeside Tales, p. 20) makes reference to the following: "It was one of the superstitions of the times that if the perpetrator of a murder could by any chance see through beneath the body of his victim, he would escape the punishment of his crime. So far from proving always true, this belief had sometimes even led to the detection of the murderer, when he might otherwise have escaped. Cases have been known where, during the funeral of a person who had met his death by foul means, the culprit was detected by displaying some anxiety to look under the coffin. This superstition also gave rise to a singular custom, long observed in the Highlands at the funerals of persons supposed to have been murdered. Before 'lifting,' the coffin was draped with Highland plaids, which hung from its sides to the ground, so that no one might be able to see through beneath it when it was being conveyed to the place of interment."

"Reistin"" a funeral.-A. M. (died in I910, aged 83) told me a tale narrated to him by his father as having happened at a funeral in Strathdon in the old days. While the coffin was being carried over a burn it became suddenly so heavy that the procession came to a stand-still in mid stream and no progress could be made. At last one old man asked if any man was present who shaved on the Sabbath day. One of those present acknowledged that he did, and was told to step forward and lay his hand on the coffin. It immediately became lighter, and the procession went forward without further difficulty. 
Alexander Thomson, schoolmaster of Strathdon, was drowned in the disastrous floods of 1829 . His body on being recovered from the river was taken to a cottage belonging to an old woman, who objected to the corpse being brought in unless it was first "carried roond the hoose." This was done; but the flood, later, rose further and reached and destroyed her house. She attributed this to the fact that the body had only been carried once round the house, and not three times. (From A. H., died rgro, aged 75.)

A local verse on the drowned schoolmaster runs:

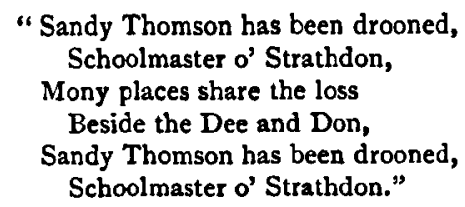

A Resurrectionist Story.-In the parish of Newhills, at the beginning of last century, a funeral had been in progress. The "tyke-wake" had been unduly prolonged for two days in a barn, until the whisky had run low. One of the company was dispatched for more, and, during his absence, the coffin was, as a practical joke, set up on end outside the door to scare him on his return. He duly reappeared with the fresh supplies, but to the surprise of the rest of the company made no remark about the coffin. At last one man said, "Did ye nae see onything as ye cam' in?" "Na!" he replied, "Fat wis there to see?" And on going out the assembly duly found there was nothing to see. Some resurrectionists who had happened to pass had seized the opportunity and the coffin with its contents, which never was seen again.

\section{"Canny Folk."}

In the fishing villages, in the old days, were certain people, men and women, whose advice it was well to take before setting out to sea or on other important occasions. In the village of Newtonhills, Kincardineshire, such a "canny man" was, thirty years ago, called into and kept in the house during the progress of a tedious labour, with the idea that his presence would influence its progress favourably. 
Birth.

If a child cries lustily after it is born, the bystanders say, "It's gat a gueed brain, ony-wye." "Ye may say fat ye like, but I ken this o't," said an old woman, "oot o' a' my ten, my aul'est laddie wis the only een that grat maist awfu' fan he wis born, an' he's been cliverer than ony o' them."

A premature child will live if born at the seventh month, but not at the eighth.

If twins should get husbands and wives, one of them will be childless.

A doublewhorl in the hair of a child means that it will live to see two kings crowned, or that it will be "a great wanderer."

In olden days two mutches (caps), an inner plain one and an outer one of a more ornamental variety, were put on the child's head. The first inner one, taken off when soiled, was never washed and put on again, but flung in the fire. Similarly, the first soiled napkin was never washed and used again, but was flung out on the green. (Durris, Kincardineshire.)

Children baptized after dark will see "bokies" (ghosts). (Parish of Kaig.)

\section{Sundry Beliefs and Sayings.}

Crows building near a house bring luck.

Swallows building also bring luck. It is very unlucky to harry a swallow's nest. A swallow flying beneath the arm causes paralysis of the arm.

If a woman loses her marriage-ring "she will lose her man."

It is unlucky to put boots on the table, but the ill-luck may be counteracted by spitting on the soles. Some years ago, after examining and condemning a pair of narrow-toed boots in a ploughman's house, I placed them on the table, and the ploughman's wife immediately removed them, saying, "Would ye hae strife in the hoose afore nicht?" She was consoled when I told her, what she did not know, how the evil might be averted.

It is unlucky to open an umbrella in a house: it presages a death.

It is unlucky to pick up your umbrella yourself if you drop it. 
It is unlucky to write a prescription on black-edged notepaper.

It is unlucky to shake hands twice when saying good-bye.

If shingles meet round the body, the illness will be fatal.

If your left ear burns, your lover is thinking of you; if your right ear, your mother is thinking of you.

If the wind changes when you are "making a face," your face will permanently keep the expression: said as a warning to children.

\section{Proverbs and Sayings.}

"There's great stots in Ireland, but they canna win oure for their horns"; said contemptuously to a boaster.

"We maun just mak' o' the warl' as the warl' wull mak' wi's." .

"The crab fills wi' the corn."

"Foul saut's gueed eneuch for hairy butter."

"There's but an ill year betwixt a rich man an' a peer (poor); said of farmers."

"Ye never see them gaen fae Auchtermair to Auchterless"; said of ministers.

"I dinna bile my cabbages twice"; said when asked to repeat a remark.

"The fire's the bonniest flower in the garden"; said in cold weather.

"A len' should aye gae lauchin hame"; i.e. should be returned with some small addition.

"He's feared o' the death he'll never dee"; said of a nervous man.

"There is a toon ayont the sea,

They ca't the toon o' Ayr,

$A n^{\prime}$ them that winna dae weel here,

Winna dae weel there."

(Aberdeen Evening Express, Ap. 11, 1907.) Cr. Horace, "Colum non animum," etc.

\section{Local Proverbs.}

Fyvie.- " The parish o' Fyvie's sap, tends to run into the cap." Tomintoul.-It is said that the Deil when flying over Tomintoul says, "Bonny Tomintoull ye're a' my ain bairns!" Probably of Protestant origin, as there are many Catholics there. 
Buchan._- There's rowth (plenty) o' a'thing in Buchan, haud awa' freet (fruit)."

Micras.-Of Micras, Deeside. "There's nae an honest man in Micras but een (one), an' he stole the cannas" (the canvas on which grain was flailed); used in Micras eighty years ago.

Strathdon. - "Ye can aye tell Nochty-side loons by 'thee,' 'thou,' an' 'Wilta'"; said in Strathdon eighty years ago. Glen Nochty opens into Strathdon.

Pitfodels. - "Pit fae ye Pitfodels, there's men i' the Mearns!" the Slogan of the Menzies of Pitfodels.

The Mearns._- "The men. o' the Mearns canna do mair than they may." This saying is said to have originated from an unsuccessful attack made by the men $o^{\prime}$ the Mearns on some caterans in the castle of Birse.

Weather Lore, Seasons, etc.

A caul' May an' a windy

Maks a full May an' a findy.

May birds are aye cheepin'.

May cats are aye meutin' (mewing).

$O^{\prime}$ marriages in May

Bairns die in a dreay.

When the sky's like the waves o' the sea

Wet weather it will be.

"The Gab o' May": cold weather at the beginning of May.

"The Teuchat (lap-wing) Storm": coarse weather at middle or end of April.

"The Cauld Kalendars o' May."

"The Reedie Rows o' May" : large waves that come rolling in, on otherwise calm days in May. (Footdee, Aberdeen.)

"The purse-mou" - lines of clouds converging towards one end : a forerunner of rough weather.

Black cumuli-nimbus clouds sometimes described as "awfu' swine-looking clouds."

"Goat's hair"-a cloudy sky resembling this is indicative of wind. 
Beef-brose an' bannock day

Please let us home,

For a' the folk in oor toon

Hae gone to Foggie loan.

(Said by Rothienorman school children on "Faster's-even." The custom was for the children to write this on the black-board before the master came in, and he, when he saw it, granted the holiday.)

"Next comes Candlemas, and then the new meen, An' the first Tuesday after that is aye fasteren-e'en." (Dinnie's History of Birse.)

A harden Sabbath's a linen week. (A coarse Sunday is followed by a week of good weather.)

Three bad Sundays will be followed by a week of fine weather.

"East and Wast

The sign o' a blast,

North and Sooth

The sign o' a drooth."

(Said of the disposition of clouds in the sky.)

"Of fat's before, ye'll hear no more,

But fat's behin', ye'll bitterly fin."

This is said of parhelia, or mock suns. If seen to the east (i.e. "behind the sun"), they are of ill omen: if to the west (i.e. "before the sun"), they are of no moment.

"Fin the sea's at Aberdour,

The ill weather's a' ower,

But fin the sea's at Auchentumb

The ill weather's a' $t$ ' come."

(I.e., It is considered a sure prognostication of coming bad weather when the noise of the waves beating on the rocky coast of Buchan is heard far inland.) 


\section{Nursery Tales and Children's Songs.}

\section{The Bannockie 1}

A mannie and a wifie pit oot a bannockie to dry, an' it ran owre the hills an' owre the hills till it cam to twa waal washers. "Fat a bonny bannockie," they said: "far cam ye fae?"

"I cam fae a wee wee wifie an' a far less mannie, an' noo I've come to you."

They flung their tubs at it; an' it ran owre the hills an' owre the hills till it cam to twa barn thrashers. "Fat a bonny bannockie," they said: "far cam ye fae?"

"I cam fae a wee wee wifie an' a far less mannie, twa waal washers, an' noo I've come to you."

They flung their flails at it; an' it ran owre the hills an' owre the hills till it cam to a mannie an' his clogs. "Fat a bonny bannockie," he said: "far cam ye fae?"

"I cam fae a wee wee wifie an' a far less mannie, twa waal washers, twa barn thrashers, an' noo I've come to you."

He flung his clogs at it; an' it ran owre the hills an' owre the hills till it cam to a shepherd and his dogs. "Fat a bonny bannockie," he said: "far cam ye fae?"

"I cam fae a wee wee wifie an' a far less mannie, twa waal washers, twa barn thrashers, a mannie an' his clogs, an' noo I've come to you."

He set his dogs at it ; an' it ran owre the hills an' owre the hills till it cam to a tod in the burn. "Fat a bonny bannockie," it said : "far cam ye fae?"

"I cam fae a wee wee wifie an' a far less mannie, twa waal washers, twa barn thrashers, a mannie an' his clogs, a shepherd an' his dogs, an' noo l've come to you."

The tod shook its tail at it; an' it ran owre the hills an' owre the hills till it cam to a craw on the dyke. "Fat a bonny bannockie," it said: "far cam ye fae?"

1Three versions of "The Wee Bannock," from Ayrshire, Dumfriesshire, and Selkirkshire, are given in Chambers's Popular Rhymes of Scotland. The Aberdeenshire one is the only one where the bannock survives its visit to the tod (fox). - Cruden. 
"I cam fae a wee wee wifie an' a far less mannie, twa waal washers, twa barn thrashers, a mannie an' his clogs, a shepherd an' his dogs, an' a tod in the burn, an' noo l've come to you."

The craw flapped its wings at it an' it flew owre the hills an' owre the hills till it flew back to the mannie an' the wifie, an' they catched it.

\section{The Mousie and the Rotten.}

A mousie and a rotten were to try a race to America. The mousie fell and broke its hinch, and gaed to the souter to get it shewed.

"Souter, souter, shew my hinch unto my pinch, and lat me win my wasie."

"Na, awyte no," says the souter, "I winna shew your hinch unless ye gang to the soo for birse to me."

"Soo, soo, birse me that I may birse the souter, the souter shew my hinch unto my pinch and lat me win my wasie."

"Na, awyte no," says the soo, "I winna birse ye unless ye gang to the brewster wife for bran to me."

"Brewster wife, brewster wife, bran me that I may bran the soo, and soo, soo, birse me that I may birse the souter, the souter shew my hinch unto my pinch and lat me win my wasie."

"Na, awyte no," says the brewster wife, "unless ye gang to the coo for milk to me."

"Coo, coo, milk me that I may milk the brewster wife; brewster wife bran me that I may bran the soo; the soo birse me that I may birse the souter; the souter shew my hinch unto my pinch and lat me win my wasie."

"Na, awyte no," says the coo, "unless ye gang to the barn-man for strae to me."

"Barn-man, barn-man, strae me, that I may strae the coo; and coo, coo, milk me that I may milk the brewster wife; brewster wife bran me that I may bran the soo; soo, soo, birse me that I may birse the souter; souter, souter, shew my hinch unto my pinch and lat me win my wasie."

The coo got the strae, the brewster wife got milk, the soo got the bran, the mousie got the birse, and the souter shewed its hinch, and the mousie was first in America. 
There was a wife an' she dee't, an' her man green't [longed for] for her liver. He took it oot an' roastit it an' ate it ; an' she cam in ae day. He said :-

"Fat maks your feet sae braid?"

"I've gaen mair than ever I've read."

"Fat maks your een sae howe?"

"It's lyin' sae lang amon' the dowe."

"Fat gars your guts hing oot?"

"It was you! It was you!" (Cruden.)

Gowf ba', cherry tree,

Catch a bird an' gie it me,

Let the tree be high or low,

Let the weather be frost or snow.

Gowf ba', cherry tree,

How many apples do you give me?

One for the leddy, an' anither for the laird,

An' anither for the little boy that sits in the yaird.

(Old Aberdeen, eighty years ago.)

Whistle Bairdie had a coo,

White and black aboot the mou,

Wasna that a dainty coo

Belonged to Whistle Bairdie?

Ting-a-ling-a-long-tong, Fa's that 'at's deid?

Aul' Cattie Gilbert, Wi' a sair heid.

$A$ ' them 'at kent her

Fan she wis alive,

Come till her beerial

Atween fower an' five.

Brose an' butter an' a',

Sowens an' succar an' $a$,'

$A n$ ' isna she verra weel aff

'At gets brose an' butter an' $a$ '?

Honey an' ham, an' jeely an' jam, An' a skate like a barn-door. 
Dance to your daddy, my little lady, Dance to your daddy, my bonny lamb, An' ye'll get a fishie in a little dishie, An' a whirligiggie an' a supple Tam.

We are a' King William's men, Ma thurie an' my thorie, An' we are a' King William's men Within a golden sorie. ${ }^{1}$

Pit the doggie to the mill, This gait an' that gait, Tak' a lick oot o' this wifie's pyock, An' a lick oot o' the neist wifie s pyock,

An' a drink at the mill dam, An' gang hame, loup for spang, loup for spang, loup for spang!

My father an' mither wis Irish, $\mathrm{An}^{\prime}$ I am Irish too,

I boucht a fiddle for ninepence, An' it wis Irish too, An' $a$ ' the tunes 'at it could play Wis "owre the hills an' far away," I bruck it here, I bruck it there, An' I bruck it through the middle.

As I gaed by my aunty's door My aunty wis suppin' sowens, I socht a sup, I got a sup, I socht a suppy mair; She gaed me in the moo Wi' the red het spurtle, An' burnt it an' left but a hair. An' here's it !

(Parish of Cruden.)

'Cf. Shetland carol, "We are a' Queen Mary's Men." County Folklore, vol. iii., p. 253. 
Fan I wis een

I gaed my leen,

Fan I wis twa

I shot a craw,

Fan I wis three

I clim'ed a tree,

Fan I wis four

I gaed a glour,

Fan I wis five

I didna thrive,

Fan I wis sax

I got my smacks,

Fan I wis siven

I gaed to Stanehiven,

Fan I wis aucht

I carried a fraucht,

Fan I wis nine

I muckit the swine,

Fan I wis ten

I killed a hen,

Fan I wis eliven

I cam fae Stanehiven.

Fan I was twal

I fell into the draw-waal,

Fan I wis thirteen, fourteen

I gaed to Aikey Fair,

Fan I was fifteen, saxteen

Fat to dee there?

Fan I was seventeen, auchteen

To buy an auld meer,

Fan I was nineteen, twenty

She was owre dear.

(Parish of Cruden.) 


\section{Children's Singing Games.}

Little Sally Walker sitting in the sand, Crying and weeping for a young man.

Rise, Sally, rise and wipe away your tears, Fly to the East and fly to the West, Fly to the one that you love best. There's a couple got married in joy, First a girl and then a boy,

Seven years after and seven years to come This young couple may rise and be done. Up streets, down streets and a penny glass, Isn't . . . a nice young lass? But isn't . . . as nice as she? Both to be married and they canna agree. Clean bright candlesticks, clean fireside, Draw back the curtains and let's see the bride.

$\mathrm{A}^{\prime}$ the men in oor toon lives a happy life, Except . . . and he wants a wife. A wife shall he hae, and a widow shall he be, For look at . . ., she sits on his knee. She paints her face and she curls her hair, And she kisses her lad at the foot o' the stair.

The wind and the wind and the wind blows high, And the rain comes pattering from the sky. ... says she'll die,

For a lad on the rolling high.

She is handsome, she is pretty, She is the flower of the golden city, She has got lovers, one, two, three, Pray and tell me who they be? ... says he'll have her,

In his bosom he will clasp her, Lash the whip and away we go, Off to Newcastle races $O$ !

Wattery, wattery well flowers, spring up so high, We are all maidens and we must all die, 
Except . . and she is the youngest one.

She can kick and she can fling,

And she can turn the sofa.

$O$ fie, fie for shame,

Turn your back to the walls again !

We are two lovers come from Spain,

All in French garlands,

We've come to court your daughter Jane,

So adieu to you, my darlings.

My daughter Jane, she is so young, All in French garlands,

She cannot bear your flattering tongue,

So adieu to you, my darlings.

If this young man should chance to die, And leave his wife a widow,

The bells shall ring, and the church shall sing, And we'll all clap hands together.

So a-doaving, a-doaving, A-doaving by the hand, We'll take this pretty fair maid, We'll take her by the hand.

Counting out Rhymes.

Eetam, peetam, penny pie, Pap-a-lorrie, jinky-jye, Stan' ye oot-bye

For the bonnie penny pie.

Eenerie, twa-erie, tuckerie, taiven, Alamacrackerie ten or elaiven, Peen Jean, muskey dan, Teedlum, Fodlum, twenty-wan. 
Written in Books.

If onybody gets a len'

Be's gude as sen' it hame again.

is my name,

Scotland is my nation, is my dwelling-place,

A pleasant habitation;

And when I'm dead and in my grave

And all my bones are rotten,

Tak' up this book and think on me

When $I$ am quite forgotten.

Old Songs.

I set spurs to my neadie An' awa I did ride,

To fair Lunnon city Seekin' for a bride.

The girls they cam efter me,

By one, by two, by ten,

I taul them I would mairry,

I taul them I would mairry,

I taul them I would mairry,

But I never taul them when.

I aince had a sweetheart

I loved her as my life,

An' oftimes I thocht

I would mak her my wife. 
But she proved false to me,

For she loved all sorts o' men.

I taul her I would mairry,

I taul her I would mairry,

I taul her I would mairry, But I never taul her when.

I coorted a widow

Who had great stores of gold.

I coorted her till she gave me

Nine hunner pounds an' ten.

An' I taul her I would mairry,

I taul her I would mairry,

I taul her I would mairry,

But I never taul her when.

I set spurs to my neadie An' awa I did ride,

To fair Lunnon city, Seekin' for a bride.

The girls they cam efter me, But catch me if you can,

For I taul them I would mairry, I taul them I would mairry, I taul then I would mairry,

But I never taul them when.

I am a rantin' aul' maid An' I've been single lang, I took into my aul' heid

That I would like a man.

Chorus: Fal al the diddle al, Fal al de day, Fal al the diddle al, Fal al de day. 
I gaed to a singin' class, And bonny lads were there,

The first that took my fancy Was ane wi curly hair.

He said to me, "My bonny lass, Fat wye div ye gang hame?"

Richt modestly I answered him. "The very wye I came."

He said to me, "My bonny lass, Fat like's the ane ye lo'e?"

Richt modestly I answered him, "He's richt like you."

He said to me, "My bonny lass, Fat is't they ca' your name?" Richt modestly I answered him, "They ca' me Meg at hame."

He said to me, "My bonny lass, Am I the lad ye lo'e?"

Richt modestly I answered him, "Ye've guessed richt noo."

Parish of Cruden.

As I gaed by yon toonie farm

A barkie cam oot an' doggit at me, I took my flauchter shooder fae aff my spad

I gaed it such a lug i' the lasher,

I gart a' its water een again.

(A nonsense recitation with the words transposed.-Parish of Cruden.)

"Fustle, fustle, aul' wife, An' I'll gie ye a hen."

"I couldna fustle Altho' ye gied me ten."

"Fustle, fustle, aul' wife, An' I'll gie ye a coo."

"I couldna fustle

Altho' ye gied me two." 
"Fustle, fustle, aul' wife, An' I'll gie ye a man."

" $F-f-f-f-$ [Imitation of unsuccessful whistling.] I'll dee the best I can." 1

My ae string walletie,

My twa string walletie, My three string walletie, $O$, weary fa' your dogs, gude wife, They're rivin' a' my walleties !

(Strathdon, ninety years ago.)

DAvid RORIE, M.D.

Folklore Notes from Piedmont, III.

(Continued from vol. xxiv. p. 364).

On the evening of the first of May the boys of the village in Piedmont, Savoy, and Provence, still practise the very ancient custom of planting a pine tree covered with garlands in front of the house of the most beautiful girl in the hamlet.

In Haute Savoy, on the first Sunday after Easter, in all the villages which are near a common, the children bring bundles of wood and effigies made of reeds, which they burn, and dance round the fire, all the time uttering a sort of wail.

Estella Canzian.

Folklore from Newmarket, Cambridgeshire.

Frogs.-Grooms catch a frog and keep it in a bottle or tin until nothing but the bones remains. At the new moon they draw these up stream in running water; one of the bones which floats is kept as a charm in the pocket or hung round the neck. This

'A variant of this is in Chambers's Pop. Rhymes of Scolland. 